\title{
Specific Features of ESP Classes in Developed and Developing Countries: A Multiple Case Study at Two Universities in Austria and Bosnia and Herzegovina
}

\author{
Džalila Muharemagić \\ University of Bihać
}

The paper presents results of a multiple case study on specific features of ESP classes conducted at two universities, one in Austria as a developed country and one in Bosnia and Herzegovina as a developing country. Drawing on current theoretical and practical research in ESP, the case study focuses on the most important elements of ESP classes in terms of students and subject area needs, authentic materials, content language, teaching methodology and other didactic requirements. The purpose of the study is to determine to which extent the English language courses in B\&H higher education fulfill the requirements of ESP methodology and principles, and provide insight into ESP practices in developed countries, in this specific case Austria, comparing them to those in developing countries, i.e. Bosnia and Herzegovina. The results indicate strong differences between the universities in terms of institutional commitment to organization of the courses and development of language skills of students, while the working conditions and lack of systematic approach to needs analysis were similar at both institutions.

Keywords: ESP, developed and developing countries, case study

\section{INTRODUCTION}

Considering the fact that English language has become a lingua franca in almost all fields of academic, scientific and economic activity and cooperation, it comes as natural to understand that improvement of communication skills of citizens of developing countries will support development and internationalization of those countries. Bosnia and Herzegovina as a developing country entered the Bologna process and submitted a membership request for EU with an aim of becoming a part of global movements in economy, science and education. Yet, the true entrance to the globalized world is possible once its citizens have all the necessary skills for life and cooperation in a global village such is the world of today. Besides the essential skills required by a workplace, a business partner or customs of a certain culture, communication skills are indispensable element for success in any profession. Education in Bosnia and Herzegovina has a long tradition of development of communication and language skills of its citizens; however the question is to what extent this tradition is in line with requirements of the modern language teaching and communication. On the other hand, starting from the same premises of importance of communication and lingua franca for different fields of human activity, it is natural to expect that developed countries, such as Austria, follow the latest findings in language learning and communication. Having in mind English as a lingua franca in today's world, it is also necessary to mention English for Specific Purposes as a special field of English language teaching which is dedicated to purpose of language learning, i.e. different fields 
of human activity. Following the above stated premises, an idea was born to research and compare specific features of ESP classes at two countries, one developed and one developing, and compare to what extent these countries differ in organization of the classes and fulfillment of requirements of ESP methodology in terms of students and subject area needs, authentic materials, content language, teaching methodology and other didactic requirements. The research should provide insight into best practices in ESP courses design and implementation in developed countries for relevant bodies in Bosnia and Herzegovina working on the improvement of English language courses at higher education institutions. In addition, the results may be useful for interested stakeholders in Austria in getting the external perspective of the current situation of ESP at one of their universities.

\section{THEORETICAL BACKGROUND AND RESEARCH METHODOLOGY}

In order to determine the latest findings in language learning and specific features of ESP, theoretical background of the research is primarily based on several definitions of Languages for Specific Purposes and English for Specific Purposes such as the one of Strevens (1977), Munby (1978), Hutchinson and Waters (1987), Dudley-Evans and St. John (1998). These were followed by research of Basturkmen (2010), Belcher (2009), Anthony (2007), Widdowson (1983), Douglas (2000), etc. Drawing on such theoretical background, the following specific characteristics were identified as relevant for the research: needs analysis, roles and challenges of an ESP teacher, syllabus design and development of teaching materials. In his paper from 1977, Strevens states the three main principles in defining Languages for Specific Purposes: purpose of language learning; content of the language determined by the restriction, selection, themes and topics, and communication needs; any methodology appropriate for the language learning situation. Although different in content, definitions of ESP given by Hutchinson and Waters (1987) and Dudley-Evans and St. John also emphasize purpose, methodology and content as main elements of ESP. It is important to state that the purpose itself is not exclusively reserved for ESP, but rather in ESP it is the awareness of purpose that differs it from General English and this is where needs analysis plays a role. A model of needs analysis used in the research to some extent, combines several approaches and is best explained by Basturkmen (2010:19). This includes elements of the following: Target situation analysis, Discourse analysis, Present situation analysis, Learner factor analysis, Teaching context analysis.

The research was designed as a multiple case study which according to Yin (2003; according to Baxter and Jack, 2008:548) enables a researcher to explore differences within and among two or more cases, where the cases should be carefully selected enabling the researcher to forecast the results based on the theoretical background. Yin (2009) explains that the case study should explore a phenomenon in its realistic context through a specific situation by means of multiple research techniques and using theory as the basis for the research. The phenomenon of this study is ESP teaching in its realistic context of higher education in developed and developing countries, while the specific situations are two universities in Austria and Bosnia and Herzegovina with its specific ways of organization of ESP classes. Finally, as stated in the previous chapter, the research is based on contemporary theoretical findings in the field of Languages for Specific Purposes and English for Specific Purposes. The two specific universities were carefully selected considering that both were public universities founded by state, i.e. developing and developed country at a relatively similar time - University of Applied Sciences Technikum Wien was founded in 1994 and University of Bihać in 1997; both universities have approximately similar number of students (cca 4000) and offer studies in almost similar fields - technical and biotechnical sciences and economics among others. As is specific for case study, the research used a multiple research techniques for collection and analysis of data: class observation, qualitative content analysis, surveys and semi structured interviews.

Class observation was done at both universities during summer semester of academic year 2015/16 for 40 classes at University of Bihać and 36 classes at UAS Technikum Wien (class duration of 45 minutes given in units of 1,5 hours and 2 hours). Observation was done in an authentic work and time environment of both universities, without interference of a researcher, using recommendations for class observation given by Bezinović et al. (2012). Notes on the class observation were taken according to the first part of COLT scheme given by Nunan (1992:99) - activity type, participant organization, content, student modality 
and materials. In addition, the notes included following information: class size (number of students), language spoken during the class, native language of a teacher, and equipment used.

Materials collected during class observation included teaching materials used during classes, as well as syllabus of each subject, and additional materials used for preparation of classes. The materials were analyzed using the qualitative content analysis (Dornyei, 2003) and coded according to categories of objective analysis recommended by Hutchinson and Waters (1987:99-104).

Surveying was used in order to collect data on needs analysis of students, alumni, content teachers and English language teachers. Surveying was done using questionnaires developed according to recommendations of Dornyei (2003). Besides surveys, semi structured interviews were used to collect data on working conditions of English language teachers. Interviews were conducted in line with recommendations given by Nunan (1992). While the interviews were directed towards the attitudes of English language teachers, questionnaires were designed to collect data on teaching process at the two universities containing 41 question set into four categories - general questions on teachers and their experience, general questions on the subject, questions related to the process of needs analysis, and those related to materials development. Total of 7 interviews and 20 questionnaires for teachers of English language were collected at both institutions.

Students' needs analysis was done by means of questionnaires designed in line with theoretical recommendations (Basturkmen, 2010). Total of 13 questions were set into 4 categories: general information on students, attitudes toward English language classes, questions for self-evaluation and evaluation of English classes at their university, and expectations of current and future language needs. The same categories were given in questionnaires for alumni students through 10 questions, with additional category of recommendations for improvement of English language classes according to their needs of working in a certain profession. Finally, questionnaires for content teachers consisted of 8 questions given in 4 categories: general questions, attitudes towards relevance of English language for future profession of students, questions related to contents of English language classes according to needs of the profession and recommendations for improvement of English language classes. Total of 128 students, 30 alumni and 16 content teachers of University of Bihać were surveyed in this research.

The research problem was defined through a causal and consequential relationship of a lack of institutional commitment to organization of English language classes at higher education institutions in Bosnia and Herzegovina as a developing country which leads to the lack of communication skills of its citizens for globalized labor market subsequently leading to a large number of unemployed people and obsolete economy.

Having in mind such defined research problem, the main goal of the research was to determine to what extent the existing teaching process, its organization and implementation, working conditions of English language teachers and use of teaching materials follow the requirements of English for Specific Purposes (ESP) defined by the contemporary theory and practical research in this field. Since the needs analysis is one of the main elements of ESP, another goal of the research was to determine needs for ESP classes in higher education institutions in Bosnia and Herzegovina through an example of University of Bihać from perspective of students, English language teachers, content teachers and alumni. Finally, as Bosnia and Herzegovina is a developing country committed to development and membership in the European Union, another goal is to determine positive practice in organization and implementation of English language classes in higher education of developed countries, using an example of UAS Technikum Wien. These research goals require the following research questions: 1. To what extent do the ESP classes at University of Bihać, one of the higher education institutions in Bosnia and Herzegovina as a developing country, fulfill the requirements of English for Specific Purposes (ESP) defined by the contemporary theory and practical research in this field?; 2. To what extent do the ESP classes at University of Bihać, one of the higher education institutions in Bosnia and Herzegovina as a developing country, fulfill the needs of its students, English language teachers, content teachers and alumni?; 3. To what extent do the English language classes at UAS Technikum Wien, one of higher education institutions in Austria as a developed country, fulfill the requirements of English for Specific Purposes (ESP) defined by the contemporary theory and practical research in this field?. 


\section{RESULTS AND DISCUSSION}

Analysis of collected data indicated both similarities and differences at the two institutions. Working conditions are positive and very similar at both institutions in terms of teaching equipment, class size and workload of students during semester. It is also positive that there is a regular evaluation of a teaching process conducted by students, which indicates higher level of student motivation for the teaching process itself. Furthermore, teaching staff at both institutions share the same attitudes towards the financial conditions and workload, which mostly refers to the fact that they are overloaded with classes and not paid for preparations for their classes and evaluation of students' work. Despite the similarities that the two universities share, there is a large difference in organization and implementation of English language classes, which mainly can be seen as an institutional commitment to organization of this type of classes at the developed country. First, this can be seen through an approach to organization of English language classes at the university level. The results of class observation and syllabus analysis indicated structured approach, starting from the very vision and mission of the university and their idea of humanist engineers. In addition, what is specific for this university of applied sciences is a department for languages and humanities whose primary role is development of social skills and humanist values of their students. Furthermore, this structured approach is visible through development of syllabi and teaching materials, which is done jointly by the department and content teachers, and also through organization of a conference on English language teaching which according to the surveys and interviews of teachers represents the main form of professional training and development. Finally, the university ensures continuous learning for students through organization of English language classes during all four years of study and learning outside classes through the electronic platform for English language learning called eSnack. What is also positive is the fact that students have an opportunity to learn from native speakers of English language, with lessons mostly held in English language without interference of mother tongue. This structured approach starting from the university level, over formal documents, joint work of English language and content teachers, to continuous learning of both teachers and students represents an example of good practice in institutional commitment to English language education. On the other side, organization of English language classes at a university in a developing country does not start from a university level but from a teacher who is responsible for fulfillment of all elements of English for Specific Purposes, starting from syllabus development to their own professional development. Knowing that the teacher is the only person in charge of syllabus and material development, and that according to the survey results, besides the syllabi there are no other formal documents or curricular elements dedicated to English for Specific Purposes, a lack of structured approach and institutional commitment is evident. This problem can be further tracked to the number of years of learning language which at University of Bihać is one or maximum two semesters during an eight-semesters study period. This, and also the fact that the workload is divided to classes held by an assistant and by a professor, indicates that the institution neglects the importance of continuous language education for development of communication and social skills of its students relevant for progress of the country.

Following the next goal of the research, the results of class observation, content analysis and surveys were set against the contemporary theory and empirical research in this field. Since these emphasize the needs analysis as the main element of ESP, the results at both institutions have shown that neither of the institutions conducts a thorough needs analysis recommended by experts such as Dudley-Evans and St. John (1998) or Basturkmen (2010). The fact that both institutions group students according to the field and year of study indicates presence of Target Situation Analysis and Present situation analysis. This should mean that the teaching materials, syllabi and content are in line with the tasks, activities and skills in which students will use or are already using the language. However, although syllabi at University of Bihać include some of these elements, class observation and content analysis have shown that the teaching process mostly includes grammatical exercises and presentation of the field-specific vocabulary. There is a lack of specific tasks and activities related to target needs, as well as the lack of activities for improvement of communication skills which is followed by frequent use of mother tongue in classes. Such approach does not fulfill the basic criteria for definition of languages for specific purposes given by Strevens (1977): focus 
on the purpose of language learning; content of the language determined by the restriction to skills important for the purpose, selection of language, themes and topics and communication needs related to the purpose; methodology appropriate for the language learning situation. Having the definition in mind, the results of class observation and content analysis at UAS Technikum Wien indicate greater correspondence with the criteria - e.g. teaching materials for engineering students include engineering elements such as impact analysis, process description and writing of laboratory reports; practice of communication skills is present through tasks which include discussions, negotiation, etc. Although some content refers to elements of business and ethics, which are not directly related to students' specific field (e.g. engineering), this is justifiable by the concept of the university which is dedicated to education of humanist engineers (Maderdonner, 2010) and is also in line with the internal goals of ESP teaching (Cook, 2002; according to Basturkmen, 2010). Continuing with the conclusion of the research of lack of thorough needs analysis, analysis of syllabi and survey results at University of Bihać have indicated opposed results - the teachers have stated that they are using lexical-grammatical type of syllabus, while for the type of needs analysis they have not selected discourse analysis among others. If we consider theoretical recommendations for lexical-grammatical syllabus, it is linked to the language structures and vocabulary, and therefore requires a discourse analysis which is used to determine language used in the target situation (Basturkmen, 2010). The author (Basturkmen, 2010) also states that the teaching based on needs analysis requires more detailed learning goals as opposed to the General English teaching. However, syllabi analysis at both institutions indicated generalized goals which can hinder the evaluation of efficiency of such teaching and learning. Cooperation between ESP teachers and content teachers in development of syllabi is also recognized by some authors (Dudley-Evans \& St. John, 1998) as a very important factor for ESP classes. The results of this research indicate presence of such practice at UAS Technikum Wien, while at University of Bihać teachers have indicated that they do not cooperate with content teachers in any aspect of development of English language classes. What is positive is that the results of survey for content teachers show they are willing to take part in development of syllabi and teaching materials for English language classes. Positive results at both institutions are also visible in the presence of a role of teacher as a researcher which DudleyEvans and St. John (1998) state as one of the main roles of ESP practitioner. Here teachers have confirmed that they are interested and are following the latest developments in specific field of their students. Finally, the theory of ESP emphasizes the importance of teaching materials for the future profession of students. Content analysis of collected teaching materials at UAS Technikum Wien indicates that this criterion is fulfilled since the materials mostly focus on the language, skills, discourse and genre of the students' future profession. However, in order to determine the authenticity of such materials, it would be necessary to conduct a more specific research. Analyzed materials at University of Bihać partly indicate a complete lack of connection with the future profession of students, since these materials are more linked to General English. However, some materials are linked to the specific study field of students and these are mostly ready-made commercial materials. It is important to state that different ESP experts do not share the same opinion about use of such materials, such as Belcher (2009) and Pilbeam (1987).

Final part of the research refers to the needs for ESP classes in higher education institutions in Bosnia and Herzegovina through an example of University of Bihać from perspective of students, English language teachers, content teachers and alumni. Students' survey partly provides data for those elements of needs analysis which Basturkmen (2010) identifies as Learner factor analysis, i.e. determining those factors related to the learner such as their motivation, how they learn and how they perceive their own needs; and the Present situation analysis, i.e. ,identification of what the learners do and do not know and can or cannot do in relation to the demands of the target situation". Students of University of Bihać have positive attitudes towards English language classes and consider it important for their studies and future profession. Students also consider their knowledge of English language as very good in almost all skills. Although students mostly consider that the current workload is not sufficient for their needs, most of the students have confirmed that the current classes are very useful for their current needs. With reference to the future needs, students consider these to be for the purpose of future profession and future studies, while the ideal English language classes should be in ESP and should include speaking and communication skills, every-day and professional vocabulary. Alumni needs analysis falls into the Target situation analysis (Basturkmen, 2010), 
and the results indicate that they use English language mostly for professional development, which is followed by their selection of necessary language skills. While alumni mostly use reading and writing skills for professional needs, they use speaking and listening skills for entertainment and meeting new people. All respondents consider that students studying in their specific field should be provided with ESP classes which would include professional vocabulary, speaking and communication skills. This is in line with the opinion of content teachers, who consider that students will mostly use English language for professional development, where reading skills are the most useful. They also consider that the English language classes should follow the content of the field-specific subjects and use authentic texts, in order to equip students with skills for further learning on their own. All respondents agree that the classes should be those in ESP and should include professional vocabulary and communication skills.

\section{CONCLUSION}

Three research questions have been set for this research. These were derived from a research problem of lack of institutional commitment to English language teaching in higher education institutions in Bosnia and Herzegovina as a developing country, which further causes lack of communication skills of its citizens and lack of competitiveness at the global labor market. Reflecting upon the contemporary theory of ESP and results of this research obtained through class observation, surveying and interviews, it is possible to formulate an answer to the first research question - the ESP classes at University of Bihać, one of higher education institutions in Bosnia and Herzegovina as a developing country, only partly fulfill the requirements of English for Specific Purposes (ESP) defined by the contemporary theory and practical research in this field. Conclusion for this research question and recommendation for University of Bihać would be to follow the example of universities in developed countries which have a structural approach to ESP classes and which consider these classes to be an addition to professional skills of their students and not the additional financial burden. The structural approach means that the classes are organized at the university level without being burdened on the teacher alone. Also, syllabi and the teaching materials are developed in cooperation of English language teachers and content teachers, while the lessons are organized at each study year. Reorganization of classes at University of Bihać in terms of classes being held only by one type of teachers would decrease the costs, and the extra financial resources could be directed to organization of ESP classes in more than one semester during the entire study period. Institutional approach to ESP classes which is based on the purpose of learning the language would enable better insight into needs of students and their profession. This would further enable quality education for young people including professional and social skills necessary for the global labor market. It is necessary to form a team of English language teachers and content teachers which would clearly determine educational goals in line with the needs of the labor market and students' needs, i.e. perform a needs analysis in line with the contemporary theoretical and practical requirements of ESP. More attention must be paid to education of new generations of English teachers, where a suggestion for a new research would be to determine to what extent the education of English language teachers includes education in the field of ESP.

The answer to the second research question would be - ESP classes at University of Bihać, one of the higher education institutions in Bosnia and Herzegovina as a developing country, mostly do not fulfill the needs of its students, English language teachers, content teachers and alumni. This conclusion is made upon the results of needs analysis survey done by the given categories. The results have shown that ESP is an indispensable for English language teaching at a university level from perspective of the surveyed categories. The fact that the answer to the first research question is that the English classes at University of Bihać are not in line with ESP requirements, indicates that such classes are not in line with the needs of the given categories. In addition, the survey results indicate that such classes should include communication skills, speaking skills and professional vocabulary, while the classes at University of Bihać include only the professional vocabulary. The classes mostly include grammatical exercises, with certain use of mother tongue during the English language classes, which leaves little space for practice of communication and speaking skills. Besides, the survey results indicate that the alumni use English language mostly for professional development, which means that it is necessary to provide students with practice in lifelong 
learning, more specifically in English for specific academic purposes. Elements of this form of English language teaching have not been registered in English classes during this research. Needs analysis is an inevitable element of ESP classes and must be a starting point for organization of classes which are being classified in curricula as professional English classes. Just a nominal classification of such classes as ESP or professional English classes should not be a practice of any trustworthy institution and is not in line with pedagogical standards whatsoever. The university must establish better cooperation with its students and the labor market for better insight into their needs, and new research on needs analysis for different professions in Bosnia and Herzegovina would be of great help.

Finally, the answer to the third research question would be that the English language classes at UAS Technikum Wien, one of higher education institutions in Austria as a developed country, mostly fulfill the requirements of English for Specific Purposes (ESP) defined by the contemporary theory and practical research in this field. The research conducted at the university indicates a high level of institutional commitment to English language teaching. However, the research results indicate that the institution does not conduct an overall needs analysis as is recommended by the contemporary theory of English for specific purposes. Although all observed elements of the teaching process indicate focus on the future profession of the students, it is necessary to conduct a more detailed study to determine whether this focus is in line with the needs of the students and their future profession. All in all, from the perspective of this research it is possible to consider the specific features of ESP classes at UAS Technikum Wien as a good practice of a university in a developed country. A suggestion for a new research would be to examine to what extent these practices influence the success of students and their competitiveness at a labor market.

\section{ACKNOWLEDGMENTS}

I wish to extend my special thanks to the management and staff of University of Applied Sciences Technikum Wien and University of Bihać.

\section{REFERENCES}

Anthony, L. (2007, October 5-6). The Teacher as Student in ESP Course Design. Paper presented at International Symposium on ESP \& Its Applications in Nursing and Medical English Education, Kaohsiung, Taiwan. Kaohsiung: Fooyin University. Retrieved from http://www.laurenceanthony.net/research/20071005_06_fooyin_keynote/20071005_06_fooyin_k eynote_proc.pdf

Basturkmen, H. (2010). Developing Courses in English for Specific Purposes. Hampshire: Palgrave Macmillan.

Baxter, P., \& Jack, S. (2008). Qualitative Case Study Methodology: Study Design and Implementation for Novice Researchers. The Qualitative Report, 13(4), 544-559. Retrieved from $\mathrm{http}: / /$ nsuworks.nova.edu/tqr/vol13/iss $4 / 2$

Belcher, D. (2009). What ESP is and could be: An Introduction. In D. Belcher (Ed.), English for Specific Purposes in Theory and Practice (pp. 1-20). Michigan: University of Michigan Press. Retrieved from https://www.press.umich.edu/pdf/9780472033843-intro.pdf

Bezinović, P., Marušić, I., \& Ristić Dedić, Z. (2012). Opažanje i unapređivanje školske nastave. Zagreb: Agencija za odgoj i obrazovanje \& Institut za društvena istraživanja u Zagrebu.

Dornyei, Z. (2003). Questionnaires in Second Language Research: Construction, Administration, and Processing. Mahwah, New Jersey: Lawrence Erlbaum Associates.

Douglas, D. (2000). Assessing Language for Specific Purpose. Cambridge: CUP.

Dudley-Evans, T., \& St. John, M.J. (1998). Developments in English for Specific Purposes: A multidisciplinary approach. Cambridge: Cambridge University Press.

Hutchinson, T., \& Waters, A. (1987). English for Specific Purposes: A learning-centred Approach. Cambridge: Cambridge University Press. 
Maderdonner, O. (2010, May 7-8). The Humanist Engineer. Paper presented at the 6th Austrian UAS Language Instructors' Conference, Vienna. Vienna: UAS Technikum Wien.

Munby, J. (1978). Communicative syllabus design. Cambridge: Cambridge University Press.

Nunan, D. (1992). Research Methods in Language Learning. Cambridge: CUP.

Pilbeam, A. (1987). Can Published Materials Be Widely Used for ESP Courses? In L.E. Sheldon (Ed.), ELT Textbooks and Materials: Problems in Evaluation and Development (ELT Documents 126, pp. 119-125). London and Reading: The British Council.

Strevens, P. (1977). Special Purpose Language Learning: A Perspective. Language Teaching and Linguistics, 10(3), 145-163.

Widdowson, H.G. (1983). Learning Purpose and Learning Use. Oxford: Oxford University Press.

Yin, R.K. (2009). Case study research: Design and methods (4th Ed.). Thousand Oaks: SAGE Inc. 